Article

\title{
Recent Trends of Extreme Precipitation and Their Teleconnection with Atmospheric Circulation in the Beijing-Tianjin Sand Source Region, China, 1960-2014
}

\author{
Wei Wei ${ }^{1}$, Zhongjie Shi ${ }^{2, *}$, Xiaohui Yang ${ }^{2, *}$, Zheng Wei ${ }^{3}$, Yanshu Liu ${ }^{2}$, Zhiyong Zhang ${ }^{2}$, \\ Genbatu Ge ${ }^{2,4}$, Xiao Zhang ${ }^{2}$, Hao Guo ${ }^{2}$, Kebin Zhang ${ }^{1}$ and Baitian Wang ${ }^{1}$ \\ 1 College of Water and Soil Conservation, Beijing Forestry University, Beijing 100083, China; \\ weiwei@bjfu.edu.cn (W.W.); ctccd@126.com (K.Z.); wbaitian@bjfu.edu.cn (B.W.) \\ 2 Institute of Desertification Studies, Chinese Academy of Forestry, Beijing 100091, China; \\ liuyanshu@caf.ac.cn (Y.L.); zzy100083@163.com (Z.Z.); gegbt@hotmail.com (G.G.); \\ zhangxiao978@caf.ac.cn (X.Z.); guohaomail@163.com (H.G.) \\ 3 College of Environment Science and Engineering, Southwest Forestry University, Kunming 650224, China; \\ wei-zheng-wo@163.com \\ 4 Experimental Center for Desert Forestry, Chinese Academy of Forestry, Inner Mongolia, \\ Dengkou 015200, China \\ * $\quad$ Correspondence: shizj@caf.ac.cn (Z.S.); yangxh@caf.ac.cn (X.Y.); \\ Tel.: +86-10-62824106 (Z.S.); +86-10-62824059 (X.Y.); Fax: +86-10-62824016 (Z.S.); +86-10-62824059 (X.Y.)
}

Academic Editor: Luis Gimeno

Received: 14 March 2017; Accepted: 21 April 2017; Published: 28 April 2017

\begin{abstract}
Based on the daily precipitation data from 53 meteorological stations, 11 extreme precipitation indices were selected, categorized and calculated; the temporal and spatial patterns in these indices and their teleconnections with the large-scale circulations were analyzed by the non-parametric Mann-Kendall test; and Sen's slope estimator and linear regression for the period of 1960-2014 were calculated. The results indicated that all extreme precipitation indices had spatial patterns decreasing from the southeastern to the northwestern parts of the Beijing-Tianjin Sand Source Region (BTSSR), except for the consecutive dry days (CDD), which exhibited a reverse spatial pattern. At the whole-region scale, most extreme precipitation indices showed an insignificant decreasing trend, with exceptions in the intensity indices (RX1day and RX5day) with a statistical significance at the $90 \%$ confidence level. The total annual precipitation showed a general shift towards a drier climate in the study area. Spatially, all indices for extreme precipitation showed decreasing trends at most stations, except for simple daily intensity index (SDII) and heavy precipitation days (R10). The change in extreme precipitation may be affected by the El Niño-Southern Oscillation (ENSO), East Asian Summer Monsoon (EASM) and Pacific Decadal Oscillation (PDO). Better understanding of extreme precipitation for the BTSSR may be useful in the regional planning for ecological restoration and water management.
\end{abstract}

Keywords: extreme precipitation; trend; Mann-Kendall; Beijing-Tianjin Sand Source Region; ecological restoration; atmospheric circulation

\section{Introduction}

Global change is the most important environmental issue and one of the greatest challenges facing humanity [1] as climate extremes are becoming more and more frequent [2,3]. Climate extremes can seriously impact agriculture, water resources, urbanization, and drought [4] and drive changes in natural and human systems much more than average climate fluctuations $[5,6]$. Extremes also tend to trigger floods, leading to economic damage and loss of life [7]. Because of the negative impacts 
on society and the natural environment, in recent decades, more attention has been paid to changes in extreme climate events, particularly extreme precipitation $[7,8]$. Due to the social, economic, and ecological impacts of extreme precipitation events, it is essential that hydrological, agricultural, and ecological managers and policy-makers have the information needed to better evaluate temporal and spatial variations in extreme precipitation.

In recent decades, changes in extreme precipitation have been documented through regional differences at global and regional scales. Many studies have shown increasing trends in some areas, such as Central and Southern Asia [9], the Tibetan Plateau [10], northwestern and southwestern China [11-14], eastern China [15], the Hengduan Mountains [16], and Yunnan province [17]. Alexander et al. [2] found a general global increase in precipitation indices and a slight increase in the contribution of very wet days to total annual precipitation. Lupikasza et al., investigated spatial and temporal variability in extreme precipitation indices, finding that the increasing trends in extreme precipitation dominated in central-eastern Germany [18]. Jung et al., found a significant positive trend in annual precipitation; the increase was mainly associated with the increase in frequency and intensity of heavy precipitation during the summer season in Korea from 1973 to 2005 [19]. In parallel, there have also been decreasing trends in many areas, such as the countries of the Western Indian Ocean [20], southern Poland [18], tropical regions [21], the southwestern part of Pakistan [22], and the Arabian Peninsula [23]. However, in most of these studies, changes of extreme precipitation were not found to be statistically significant.

Over the past decades, most studies have focused on revealing spatial and temporal changes in the amount, intensity, and frequency of precipitation in China. Guo et al. [11] reported that the frequency of extreme summer precipitation has increased in northwestern China over the past 50 years. Zhang and Cong also reported that precipitation significantly increased in intensity and decreased in frequency within China [24]. A study by Shao et al., found that the annual maximum daily precipitation increased slowly in the arid and semiarid regions, and more rapidly in the humid regions of China over the past 60 years [25].

Due to climate change and human activities, land in the Beijing-Tianjin Sand Source Region (BTSSR) has been seriously degraded [26]. Dust storms have transported dust into the southern part of Northern China, including Beijing, Tianjin, and Hebei. These areas have large populations and a high level of economic outputs, and the dust has further deteriorated air quality and the environment. To reverse these environmental problems, China initiated a sand source control project in 2000 [27,28]. As mentioned above, the extreme precipitation may also affect the ecological restoration and water resources, furthering the ecological control project. Therefore, understanding the spatiotemporal trends in extreme precipitation can provide an important scientific basis for the revegetation of desertified land as well as for reasonable water resource management. This is strategically significant for socioeconomic development, restoration of degraded land, and human welfare improvement in the project region.

Therefore, this study had the following objectives, to: (1) analyze the spatial patterns of precipitation extremes in the BTSSR; (2) study the temporal trends of extreme precipitation; (3) quantify the contributions of frequency and intensity to changes in total precipitation in the BTSSR; and (4) discuss the causes and implications of changes in precipitation extremes, especially their possible teleconnections with atmospheric circulations. There is no doubt that a better understanding of extreme precipitation in the BTSSR may be useful to regional planners for ecological restoration and water management.

\section{Data and Methods}

\subsection{Study Area}

The BTSSR, located in northern China $\left(36^{\circ} 49^{\prime}-46^{\circ} 40^{\prime} \mathrm{N}, 107^{\circ} 05^{\prime}-119^{\circ} 20^{\prime} \mathrm{E}\right)$, covers an area of approximately $71.05 \times 10^{4} \mathrm{~km}^{2}$. The region includes 138 counties in the provinces of Beijing and Tianjin, the central part of Inner Mongolia, and the northern part of Hebei, Shanxi provinces, and a 
small part of Shan'xi Province (Figure 1). Approximately 32\% of this region is covered by sand and desert, including the Mu Us sandland, Ortingdag sandland, western Horqin sandland, and the Kubuqi desert. The area has a typical temperate continental climate, characterized by hot-wet summers and cold-dry winters, and is dominated by arid and semi-arid conditions. The annual mean temperature varies over the region from $12.7^{\circ} \mathrm{C}$ to $-2.6{ }^{\circ} \mathrm{C}$; annual precipitation decreases from $581 \mathrm{~mm}$ in the southeast to $150 \mathrm{~mm}$ in the northwest. More than $65 \%$ of the rain falls in summer. Annual sunshine duration is approximately 2900 hours. The topography includes plains, mountains and plateaus. The plains are part of the plain of the Haihe River lying in the southeast. The mountains include Yanshan Mountains, bordering the western and southern parts. Yinshan mountains stretch from the east to the west, with peak elevation from $400 \mathrm{~m}$ to $2000 \mathrm{~m}$. The north and northwest of the study area lie in the Inner Mongolian Plateau, where the landform has a declining slope from west to east [28,29]. The BTSSR area is mostly covered by meadow, steppe, and elm savanna. Forests cover the southern mountainous part of this area. The area is divided into an inland river basin, located mainly in the northern BTSSR, and an outflow river basin, which includes the middle reaches of the Yellow River, the western Liao River, and the Haihe River.

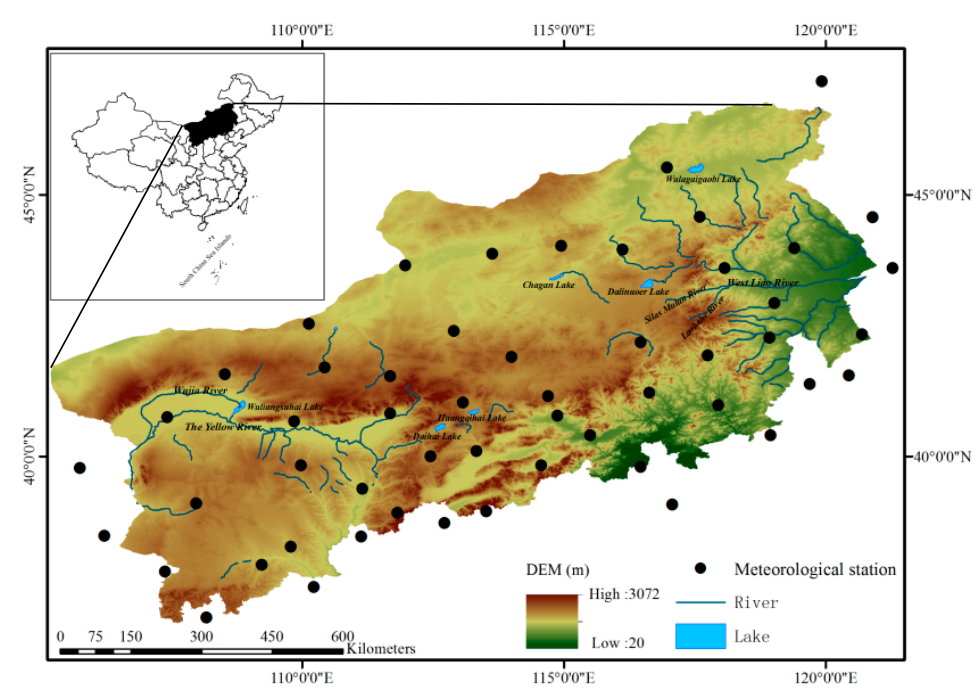

Figure 1. Locations of the study area and meteorological stations over the study region.

\subsection{Data and Process}

\subsubsection{Data Source}

Daily precipitation data from the BTSSR was obtained from the China Meteorological Data Network (http:/ / www.data.cma.cn). When less than $90 \%$ of daily precipitation data existed or more than three months contained more than $20 \%$ missing days, annual precipitation records were regarded as missing. To ensure data integrity and consistency, stations were removed that lacked more than $75 \%$ of a year's precipitation records. Missing days were not replaced with estimated daily precipitation values [30,31]. A total of 53 stations within and around the BTSSR were selected for further analysis, using data between 1960 and 2014 (Figure 1). These stations were distributed evenly across the BTSSR.

\subsubsection{Quality Control and Homogeneity Test}

Quality control tests were performed using the RClimDex package developed by the ETCCDI [32].This process eliminated errors, including errors in manual keying, negative precipitation, and outliers [2]. Daily precipitation figures with negative values were flagged as errors, and daily precipitation outliers were identified by manually examining visual data graphs and histograms. 
Suspicious outliers were identified using statistical tests, local knowledge, and comparisons with adjacent days or the same day at neighboring stations. Clearly flawed data were adjusted or removed.

Step changes at specific stations occurred for a variety of reasons, including station relocation, instrument changes, and observing procedures. As a result, the observed meteorological data were not fully comparable. To eliminate this problem, daily precipitation values were used to calculate the monthly totals; log transformations were then used to test the data homogeneity using RHtest V3 developed by Feng and Wang [33] and has been widely applied to test climate data. Possible step changes were detected using the software; metadata were then used to evaluate the changes. No station was discarded from the sample set based on these two software tests.

\subsubsection{Indices Calculation}

After quality control and homogeneity tests, nine core indices for extreme precipitation from ETCCDMI were selected, having been applied widely to evaluate extreme precipitation shifts $[20,34,35]$. Two additional indices-PPL95, indicating the percentage of heavy rain days contributing to the total precipitation [19], and R1, measuring the number of precipitation days with at least $1 \mathrm{~mm} /$ day [36] -were also included. These 11 extreme precipitation indices were then classified into four categories: (1) Frequency indices; (2) Intensity indices; (3) Duration indices; and (4) Other indices. Table 1 gives the detailed descriptions for these indices. All calculations of these indices were completed with the software RClimDex 1.0, which was developed by the Climate Research Branch of the Meteorological Service of Canada (Downsview, ON, Canada).

Table 1. Definitions of the precipitation extreme indices used in this study.

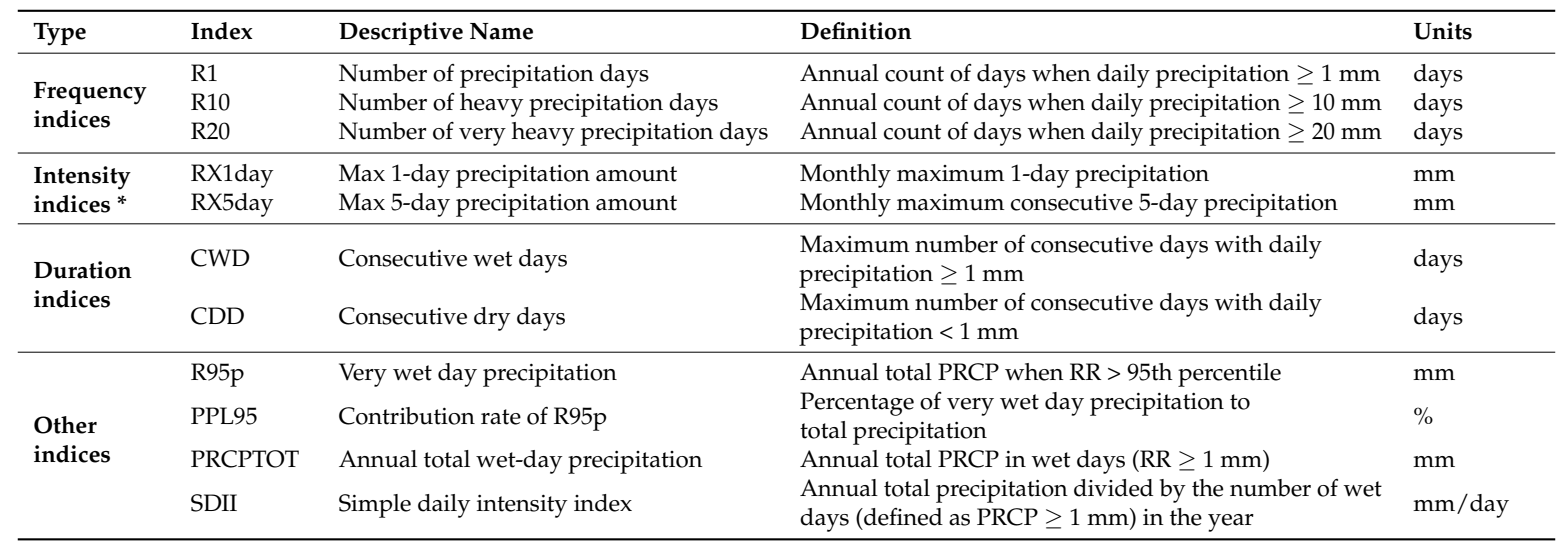

* In our study, the two intensity indices were analyzed using the annual maxima from 12 calculated indices values.

\subsection{Interpolation and Trend Analysis of Indices}

The spatial distribution of the 11 indices for the BTSSR was interpolated with the Kriging ordinary function using ArcGIS 10.2 from ESRI. As the simplest form of Kriging interpolation [37], this method interpolates irregularly distributed surface station data to create spatial data with a continuous smooth surface, and is now widely used with meteorological variables [38,39].

Trends for individual station data and regional series were estimated and the significance of the trends was determined using the Mann-Kendall test [40,41], which does not assume that data are normally distributed, and robustly responds to the effects of outliers in the series and has been widely used to test trends in hydrological and meteorological data [29,42-45], and the $10 \%$ level of statistical significance was used. Sen's slope estimator was used to estimate the true slope of an existing trend (the change per year) [46]. Before the Mann-Kendall test was conducted, the trend-free, pre-whitening method proposed by Yue et al. (2002) [47] was used to limit the effect of serial correlations on the Mann-Kendall test $[48,49]$. The trends of consecutive wet days (CWD) for each individual station can also be estimated using the Mann-Kendall test; however, many upward and downward trend 
magnitudes were zero. Consequently, to estimate the trend magnitudes of CWD for individual stations, we used linear regression. All above the calculation of these indices trend was completed with the $R$ software package.

\subsection{Relationship Between Extreme Precipitation and Atmospheric Circulations}

The El Niño-Southern Oscillation events are a coupled ocean-atmosphere phenomenon. El Niño involves warming of surface waters of the tropical Pacific in the region from the International Date Line to the west coast of South America, and associated changes in oceanic circulation. Its closely linked atmospheric counterpart, the Southern Oscillation, involves the changes in trade winds and associated tropical circulation which is encapsulated by a simple Southern Oscillation Index (SOI). The total phenomenon is generally referred to as ENSO [50]. This climate pattern's extreme oscillations cause extreme weather (such as floods and droughts) in many regions of the world, which can also affect precipitation in the BTSSR by controlling the East Asian Summer Monsoon (EASM) [51,52].

To explore the effect of circulation change in observed precipitation trend, the East Asian Summer Monsoon index (EASMI) [53] developed by Li and Zeng (2002) [54], the Pacific Decadal Oscillation (PDO) defined as the leading principal component of North Pacific monthly sea surface temperature variability [55] and the Southern Oscillation index (SOI), a measure of the large-scale fluctuations in air pressure occurring between the western and eastern tropical Pacific during El Niño and La Niña episodes indicating the strength of the Southern Oscillation [56] were used. We analyzed the relationship between precipitation indices and these indices of the circulations by correlation analysis with the R software package.

\section{Results}

\subsection{Spatial Distribution of Precipitation Extremes}

Figure 2 shows the spatial distributions of the extreme precipitation indices. All indices decrease from southeast to northwest across the study area; the exception was consecutive dry days (CDD), with a reverse spatial pattern. Among these indices, there were some significant differences in spatial distribution.

For the frequency indices, the regional average values of R1, R10, and R20 were 45.1, 10.6, and 4.0 days, respectively. For R10 and R20, the highest values were 22.7 days at Wutaishang station (R10) and 9.6 days at Qinglong station (R20), respectively. The smallest values were seen at Jilantai station, at only 2.2 for R10 and 0.8 days for R20.

For the intensity indices, RX1day and RX5day varied from 94.1 to $145.1 \mathrm{~mm}$ at Qinglong station to 21.0 and $27.5 \mathrm{~mm}$ at Jilantai station, respectively. The regional value was $45.8 \mathrm{~mm}$ for RX1day and $69.2 \mathrm{~mm}$ for RX5day. The region's rain storm center was primarily in the Yanshan Mountains, with values above 60 and $100 \mathrm{~mm}$ for RX1day and RX5day, respectively.

For the duration indices, the regional average consecutive wet days (CWD) was approximately 4.0 days. The greatest CWD value was 5.8 days at Wutaishan station and the smallest value was 2.4 days at Jilantai station. CWD decreased from the eastern and southern parts toward the northwestern part of this study area. However, CDD averaged 88 days, with a reverse spatial distribution compared to CWD. The smallest values were mainly distributed in the southwestern part of this area, at a value below 60 days; the maximal values were mainly in the northwestern BTSSR, with a value of more than 140 days.

For the other indices, PRCPTOT (total annual precipitation from events greater than $1 \mathrm{~mm}$ ) had a similar spatial distribution as the frequency and intensity indices did. It ranged from $98.8 \mathrm{~mm}$ at Jilantain station to $728 \mathrm{~mm}$ at Wutaishan station, with a regional average of $355 \mathrm{~mm}$. SDII ranged from $5.2 \mathrm{~mm} /$ day at Erenhot station to $12.8 \mathrm{~mm}$ /day at Qinglong station, with a regional average of $7.8 \mathrm{~mm} /$ day. The greatest SDII was mainly present in the southeastern part of BTSSR; the smallest values were in the middle-north region. The spatial distribution of R95p was similar to RX5day. R95p 
ranged from $25.6 \mathrm{~mm}$ at Jilantai station to $204.4 \mathrm{~mm}$ at Qinglong station, with a regional average of $91.6 \mathrm{~mm}$. PPL95, indicating the percentage of R95p to total precipitation, ranged from 19.2\% at Datong station to $27.4 \%$ at Beijing station, with a regional average of $23.4 \%$. The highest PPL95 was located in the eastern and southern parts of the study area, indicating that heavy precipitation occupies a larger proportion of those areas. The smallest values were in the northern and northwestern regions of BTSSR.

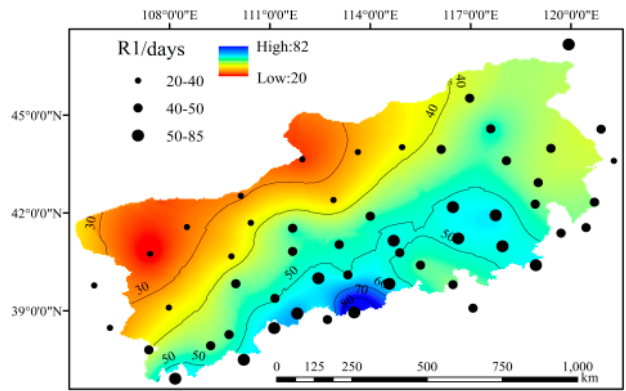

(a)

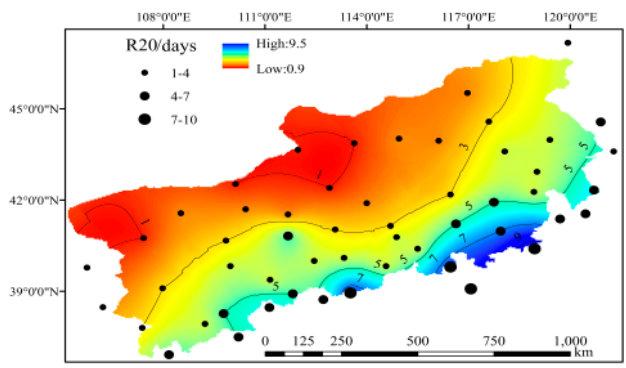

(c)

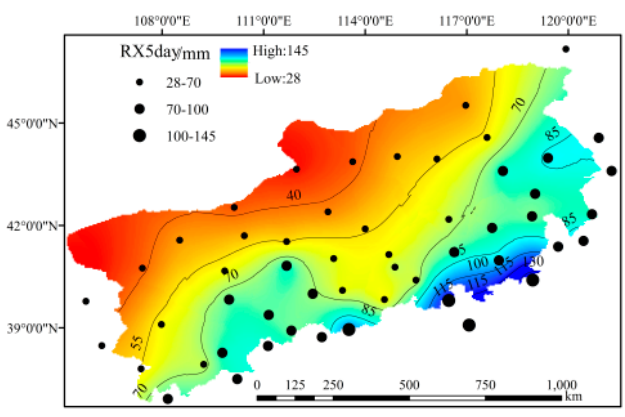

(e)

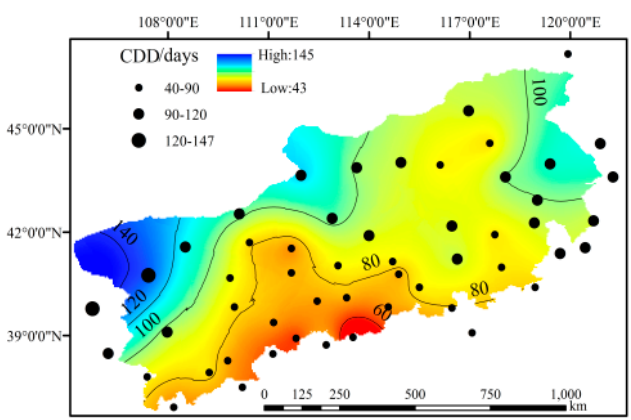

(g)

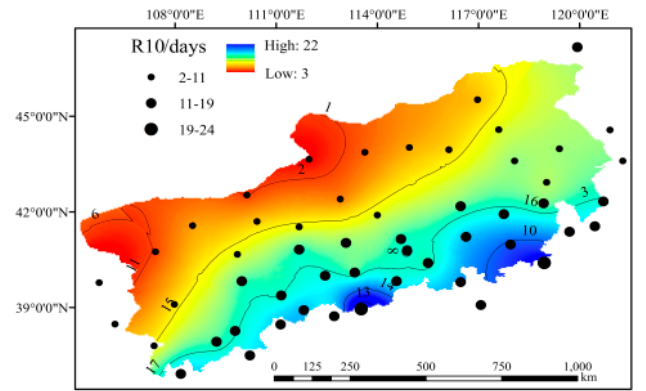

(b)

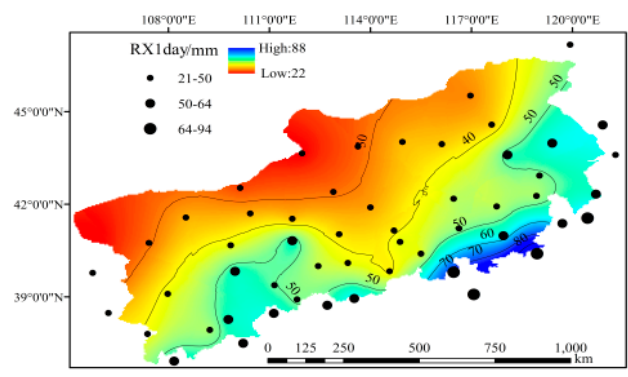

(d)

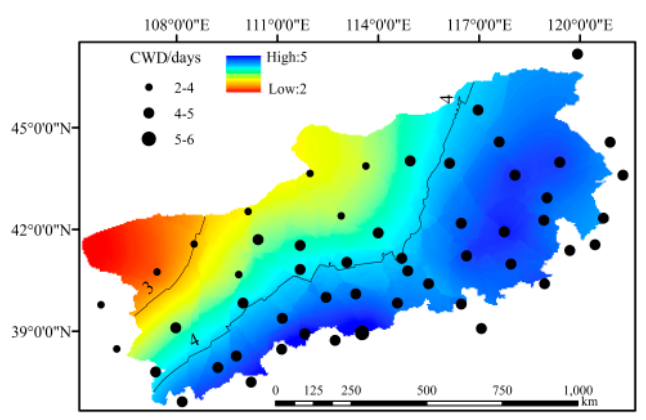

(f)

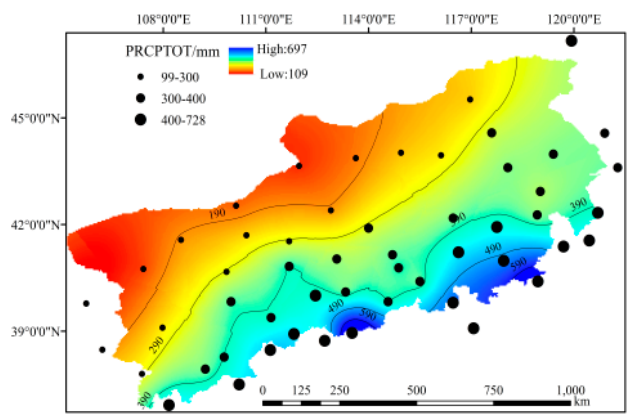

(h)

Figure 2. Cont. 


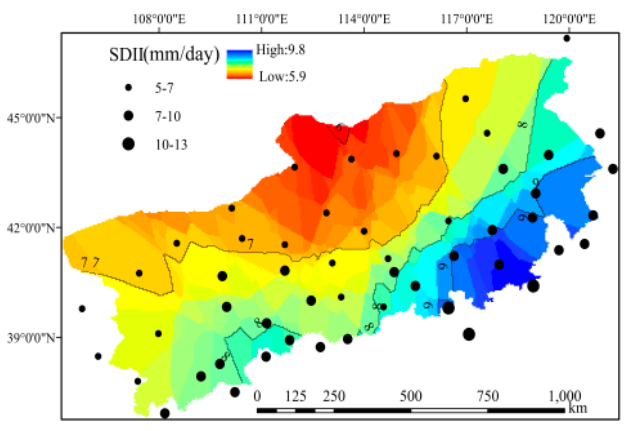

(i)

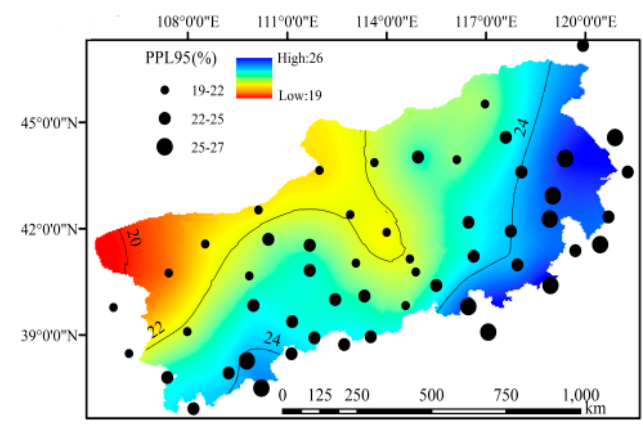

$(\mathbf{k})$

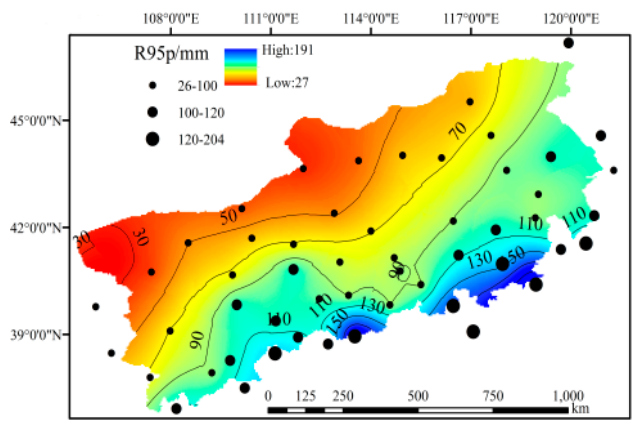

(j)

Figure 2. Spatial distribution of precipitation extremes over the BTSSR, 1960-2014 for (a) R1, (b) R10, (c) R20, (d) RX1day, (e) RX5day, (f) CWD, (g) CDD, (h) PRCPTOT, (i) SDII, (j) R95p and (k) PPL95.

\subsection{Spatiotemporal Trends of Precipitation Extremes}

\subsubsection{Frequency Indices}

Figure 3a-c show the temporal variation in regional average number of days for precipitation (R1), heavy precipitation (R10), and very heavy precipitation (R20) based on the annual arithmetic average of R1, R10, R20 for all stations. In general, the fluctuations of these indices continuously decreased from 1960 to 2014. When different periods are isolated, it appears there were no clear trends in the indices before 1980. Following this, there was greater variation, which increased until 1991. After that, there was a decreasing trend until 2000, followed by an increasing trend. Over the entire research area, the change in R1 was -0.57 days/decade based on the annual arithmetic average of R1 calculated for all stations; however, this result was not statistically significant at a $90 \%$ confidence level by the Mann-Kendall test. There was very little change in R10 and R20, at only -0.04 and -0.01 days /decade, respectively (Table 2). Over time, there were fewer days with a precipitation between 1 and $10 \mathrm{~mm}$ than with precipitation levels exceeding 10 and $20 \mathrm{~mm}$. In addition, after the ecological restoration project, these indices increased over time. 

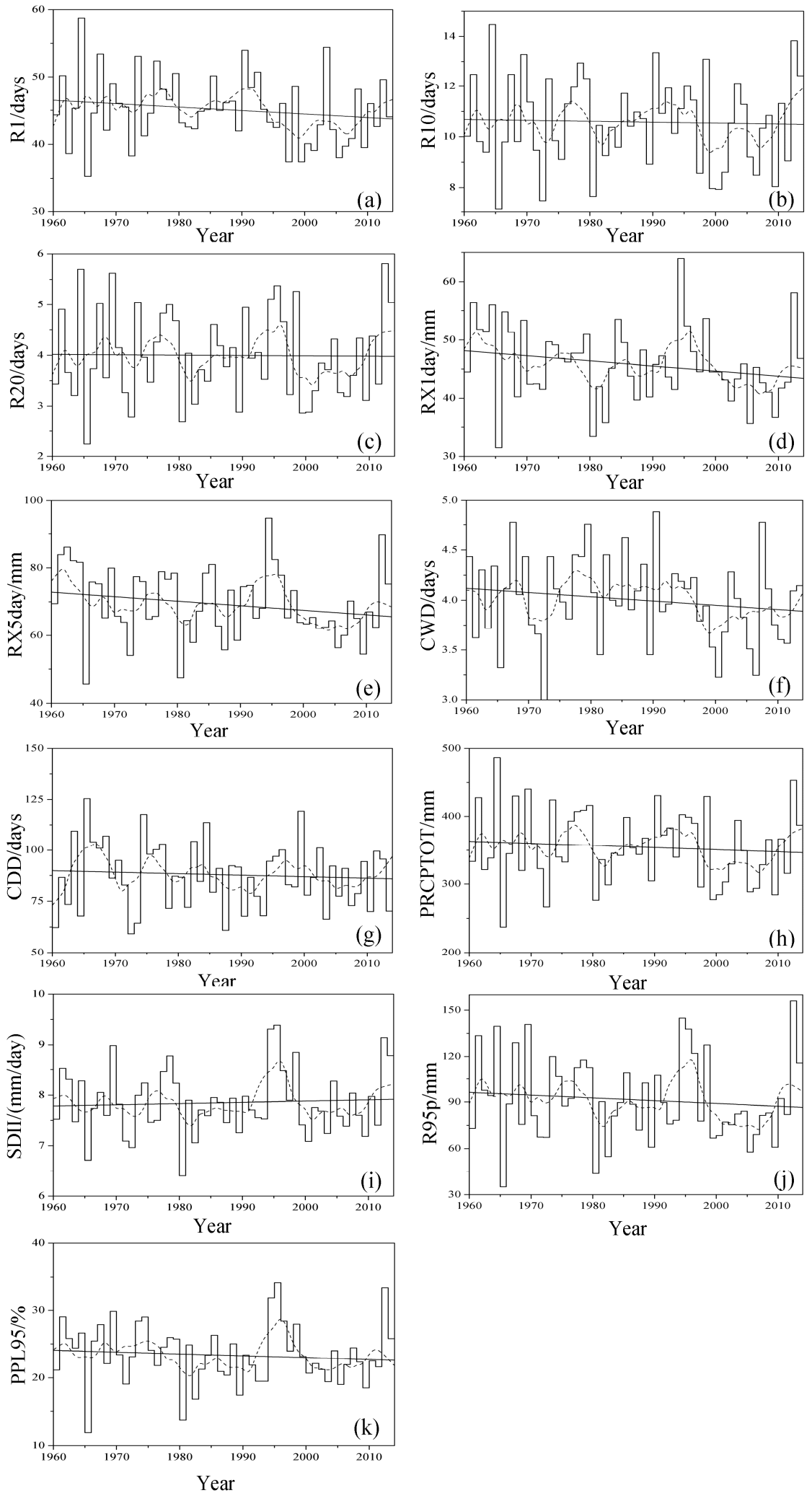

Figure 3. Regional average extreme precipitation curves. The dashed line represents the linear trends for the period 1960-2014 for (a) R1, (b) R10, (c) R20, (d) RX1day, (e) RX5day, (f) CWD, (g) CDD, (h) PRCPTOT, (i) SDII, (j) R95p and (k) PPL95. The dotted line represents 5-year moving average. 
Table 2. Statistics associated with trends across precipitation extreme indices for 53 stations in the BTSSR.

\begin{tabular}{|c|c|c|c|c|c|}
\hline Index & Trend Magnitude & Decreasing (\%) & Increasing $(\%)$ & No Trend(\%) & Units \\
\hline R1 & $-0.57(-7.69 \sim 0.59)$ & $41(77.4 \%, 11.3 \%)$ & $12(\mathbf{2 2 . 6 \%}, 0.0 \%)$ & $0(\mathbf{0 . 0} \%)$ & days/decade \\
\hline R10 & $-0.04(-1.82 \sim 0.48)$ & $23(43.4 \%, 3.7 \%)$ & $26(49.1 \%, 0.0 \%)$ & $4(7.5 \%)$ & days/decade \\
\hline R20 & $-0.01(-0.36 \sim 0.33)$ & $26(49.1 \%, 3.7 \%)$ & $23(43.4 \%, 3.7 \%)$ & $4(7.5 \%)$ & days/decade \\
\hline RX1day & $-1.41 *(-5.20 \sim 1.10)$ & $40(75.5 \%, 7.5 \%)$ & $13(24.5 \%, 0.0 \%)$ & $0(\mathbf{0 . 0} \%)$ & $\mathrm{mm} /$ decade \\
\hline RX5day & $-2.05 *(-10.30 \sim 2.90)$ & $39(73.6 \%, 9.4 \%)$ & $14(26.4 \%, 1.9 \%)$ & $0(\mathbf{0 . 0} \%)$ & $\mathrm{mm} /$ decade \\
\hline CWD & $-0.06(-0.36 \sim 0.10)$ & $32(60.4 \%, 7.5 \%)$ & $20(37.7 \%, 0.0 \%)$ & $1(\mathbf{1 . 9 \%})$ & days/decade \\
\hline CDD & $-0.81(-9.62 \sim 5.68)$ & $32(60.4 \%, 5.7 \%)$ & $20(37.7 \%, 3.7 \%)$ & $1(\mathbf{1 . 9} \%)$ & days/decade \\
\hline PRCPTOT & $-3.74(-54.53 \sim 8.16)$ & $34(64.2 \%, 1.9 \%)$ & $19(35.8 \%, 0.0 \%)$ & $0(\mathbf{0 . 0} \%)$ & $\mathrm{mm} /$ decade \\
\hline SDII & $0.02(-0.21 \sim 0.26)$ & $20(37.7 \%, 0.0 \%)$ & $33(62.3 \%, 1.8 \%)$ & $0(\mathbf{0 . 0} \%)$ & (mm/day)/decade \\
\hline R95p & $-2.89(-18.20 \sim 7.30)$ & $31(\mathbf{5 8 . 5} \%, 7.5 \%)$ & $21(39.6 \%, 0.0 \%)$ & $1(\mathbf{1 . 9 \%})$ & $\mathrm{mm} /$ decade \\
\hline PPL95 & $-0.57(-2.90 \sim 1.60)$ & $30(56.6 \%, 3.7 \%)$ & $22(41.5 \%, 0.0 \%)$ & $1(\mathbf{1 . 9} \%)$ & $\% /$ decade \\
\hline
\end{tabular}

Percentage of total stations (bold), and percentage of stations with a significant $(p<0.1)$ trend (italics), are indicated in parenthesis for both negative and positive trends; * is 0.05 level of significance.

Based on data from $22.6 \%$ of all stations, the spatial distribution of $\mathrm{R} 1$ showed an increase in the Yinshan Mountains and Eastern BTSSR (Figure 4a); however, these changes were not significant. Among the stations experiencing decrease, data from only six stations ( $11.3 \%$ of all stations) demonstrated statistically significant decrease at a 90\% confidence level. For R10, data from more than $49.1 \%$ of stations saw an increasing trend. These increases were centered on the western BTSSR and scattered on the eastern BTSSR (Figure 4b). Among these, the larger changes were seen in the midwestern part of this area. Decreasing trends were seen in data from $43.4 \%$ of stations, scattered across the study area. Of these decreases, statistically significant changes were only seen at Wutaishan and Yulin stations, at magnitudes of 1.82 and 0.29 days/decade, respectively. The spatial distribution of R20 was similar to R10, with $49.1 \%$ of stations showing decreasing trend in the station data, concentrated in the southwestern and middle parts of the area (Figure 4c). Data were only statistically significant at a $90 \%$ confidence level at two stations. In general, when considering the indices R1, R10, and R20, data from most stations showed a decreasing trend; more significant trends were seen with the R1 than for R10 and R20.

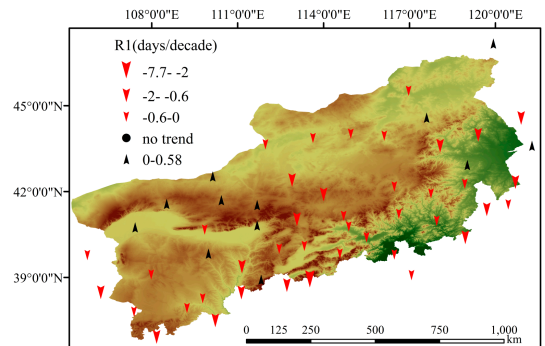

(a)

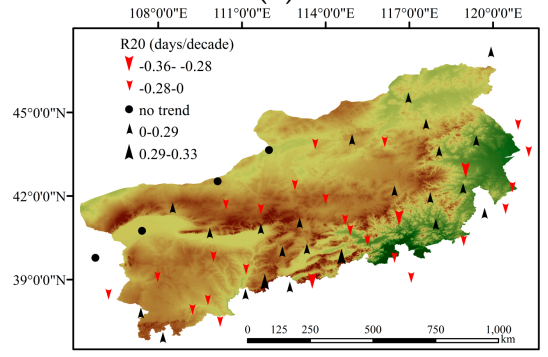

(c)

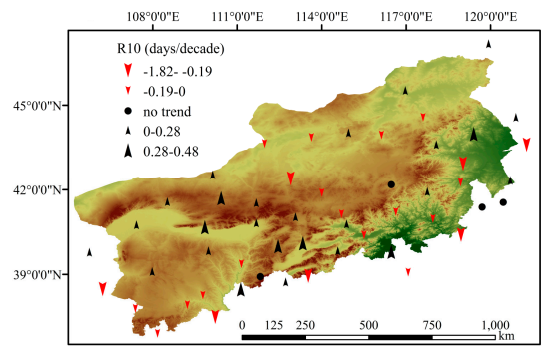

(b)

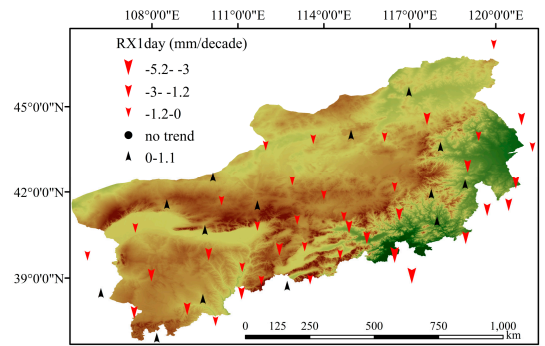

(d)

Figure 4. Cont. 


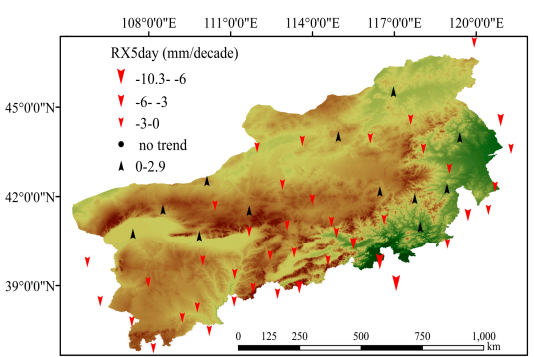

(e)

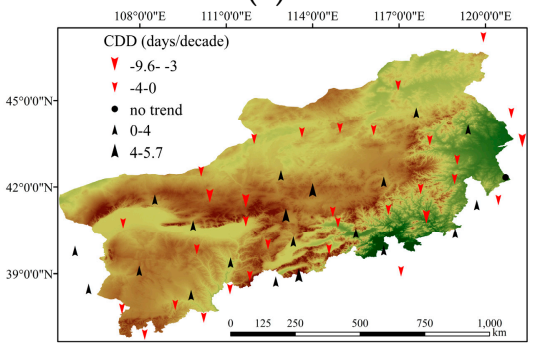

$(\mathrm{g})$

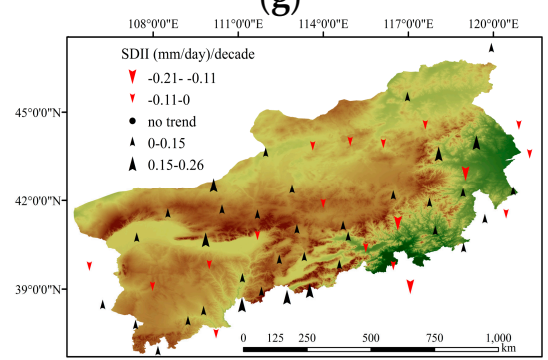

(i)

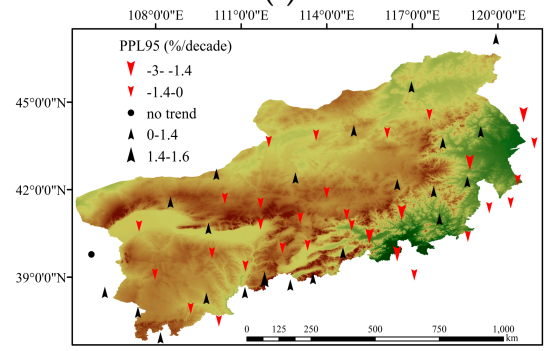

$(\mathbf{k})$

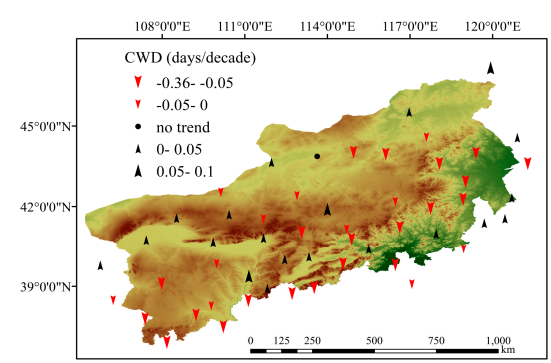

(f)

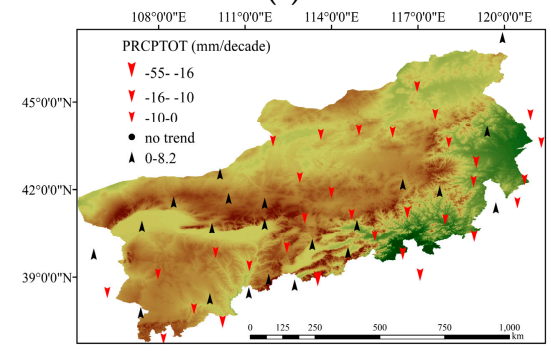

(h)

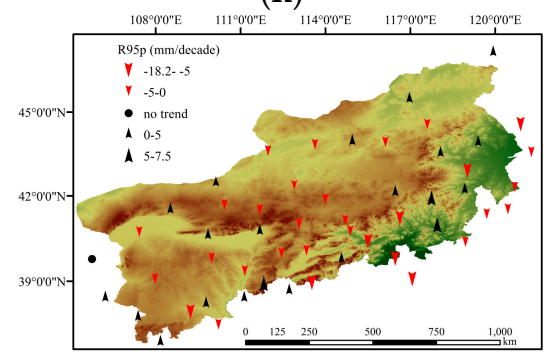

(j)

Figure 4. Spatial patterns of the trends and their magnitudes in extreme precipitation indices for 1960-2014 for (a) R1, (b) R10, (c) R20, (d) RX1day, (e) RX5day, (f) CWD, (g) CDD, (h) PRCPTOT, (i) SDII, (j) R95p and (k) PPL95. Upward (black) and downward (red) pointing triangles indicate positive and negative trends, respectively. Circular (black) indicates that there was no trend. Triangle size represents the magnitude of the trend

\subsubsection{Intensity Indices}

Figure $3 \mathrm{~d}$ shows that the regional average RX1day followed a decreasing trend, with a greater fluctuation over the past 55 years. This pattern was similar to RX5day. Before 1980, both indices followed a decreasing trend. Then, they increased until the mid-1990s, decreased until the mid-2000s, and then increased until 2014 (Figure 3d,e). When averaged across the full study area, RX1day and RX5day indices showed a statistically significant decreasing trend at a 95\% confidence level, with a magnitude of -1.41 and $-2.05 \mathrm{~mm} /$ decade, respectively (Table 2).

For RX1day, there was a decreasing trend in data from $75.5 \%$ of the stations, with an average value of $-1.27 \mathrm{~mm} /$ decade. The range was between $-0.05 \mathrm{~mm} /$ decade at Jilantai station to 
$-4.14 \mathrm{~mm} /$ decade at Beijing station. The stations located in southeastern and southwestern BTSSR showed larger decreasing trends than in other areas (Figure 4d). However, data from only four stations (7.5\% of stations) showed statistically significant decreases at a $90 \%$ confidence level. For RX5day, data for $73.6 \%$ of stations displayed a decreasing trend, with an average value of $-2.03 \mathrm{~mm} /$ decade. Values ranged from $-0.20 \mathrm{~mm} /$ decade at Youyu station to $-8.62 \mathrm{~mm} /$ decade at Beijing station. Among these stations, five stations (9.4\% of stations) exhibited a statistically significant downward trend (Figure 4e). Generally, similar spatial patterns were seen for RX1day and RX5day (Figure 4d,e).

\subsubsection{Duration Indices}

At the regional scale, both CWD and CDD displayed fluctuations, with a decreasing trend over time. CWD increased, with a larger fluctuation, until the end of the 1970s. There was then a weak decrease until 1995, stronger declines until 2000, and then an obvious increase (Figure 3f). However, CDD decreased, with fluctuations, until the 1990s, and then increased until 2014 (Figure 3g). The average CWD and CDD across the study area showed an overall negative trend, with a change of -0.06 and -0.81 days/decade, respectively (Table 2); these trends were not statistically significant at a $90 \%$ confidence level (Table 2 ).

For CWD, a decreasing trend was seen in data from $60.4 \%$ of the stations, with an average value of -0.094 days/decade. These decreases ranged from -0.36 days/decade at Wutaishan station, to -0.013 days/decade at the Yinchuan and Zhurihe stations. Data from only four stations $(7.5 \%$ of station) were statistically significant; only one station displayed no trend (Figure $4 \mathrm{f}$ ). For CDD, data from $60.4 \%$ of the stations experienced a decreasing trend, with an average of -2.32 days/decade, scattering across the study region. Data from only three stations (5.7\% of station) showed statistically significant trends (Figure 4g). The increasing trends in CDD (20 stations) and decreasing trends in CWD (32 stations) were mainly distributed in the middle and western parts of this area; significant trends were seen at the Wutaishan station, with changes of 4.83 days/decade for CDD and -0.36 days/decade for CWD (Figure 4f,g).

\subsubsection{Other Indices}

The regional PRCPTOT experienced a weak decreasing trend, with an average value of $-3.74 \mathrm{~mm} /$ decade; this was similar to R10 and R20 fluctuations (Table 2). PRCPTOT did not show an obvious trend before 1980; it then increased until the mid-1990s, then decreased until 2005, and then increased again (Figure 3h). The regional SDII displayed a very weak increasing trend, with an average of 0.016 (mm/day)/decade (Table 2). Before the mid-1990s, there was no obvious trend. In the mid-1990s, SDII abruptly increased. From the 2000s on, there was a lower daily intensity (Figure 3i). R95p decreased weakly, with a regional average value of $-2.89 \mathrm{~mm} /$ decade (Table 2). This fluctuation is very similar to RX1day and RX5day (Figure 3j). PPL95 exhibited a weakly decreasing trend at a regional scale, with an average value of $-0.57 \%$ /decade (Table 2). This fluctuation is similar to SDII (Figure $3 \mathrm{k}$ ).

The spatial distribution of PRCPTOT showed that 34 stations, accounting for $64.2 \%$ of total stations, experienced a decreasing trend, which mainly distributed in the northern and eastern parts of the study area (Figure $4 \mathrm{~h}$ ). The trend magnitudes ranged from -54.3 to $-0.42 \mathrm{~mm} /$ decade, with an average value of $-7.02 \mathrm{~mm} /$ decade; however, only data from Wutainshan station showed a statistically significant trend. Other stations experienced an increase, ranging from 0.25 to $8.16 \mathrm{~mm} /$ decade, with an average value of $3.40 \mathrm{~mm} /$ decade; these stations were concentrated in the northwestern and southern parts of BTSSR (Figure 4h). For SDII, data from $62.3 \%$ of the stations showed an increasing trend, mainly concentrated in the middle, western, and southern parts of the area (Figure 4i), and only one station revealed a statistically significant trend. The decreasing trends were scattered in the northwestern and mideastern parts of this area (Figure 4i).

R95p experienced a decreasing trend at $58.5 \%$ of stations (31 stations) with a change of $-4.25 \mathrm{~mm} /$ decade, mainly distributing in the middle, western, and southern parts of this area; however, data from four stations did exhibit statistically significant trends at a $90 \%$ confidence level (Figure 4j). 
PPL95 decreased at $56.6 \%$ of stations, at an average decrease of $-0.85 \%$ /decade; data from only two stations were significant at a 90\% confidence level (Figure 4k). Increases in R95p and PPL95 were not statistically significant. Generally, the spatial distribution of PPL95 and R95p were similar (Figure 4j,k).

\subsection{Teleconnections with Large-Scale Climate Variables}

Figure 5 shows the changes of the normalized ENSO, EASM, and PDO from 1950 to 2014. The strength of EASM is an important factor controlling precipitation amounts and extremes in our study area. The correlation analysis for the BTSSR indices shows that RX1day was significantly correlated with EASMI $(r=0.227, p<0.1)$, especially by EASMI in June $(r=0.233, p<0.1)$. RX5day was also positively correlated with EASMI; however, it was not statistically significant at a $90 \%$ confidence level $(\mathrm{r}=0.20$, $p>0.1$ ). This indicates that precipitation extremes in this area were mainly affected by EASM.

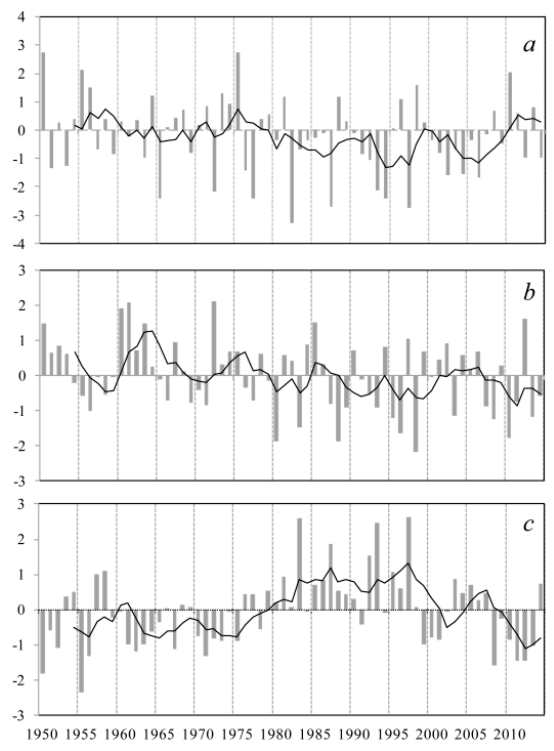

Figure 5. The changes of the normalized ENSO, EASM, and PDO from 1950 to 2014 for (a) ENSO, (b) EASM, (c) PDO.

Comparing the ENSO and extreme precipitation indices reveals that precipitation amounts and extremes were higher in the warming phase (El Niño) and lower in the cooling phase (La Niña). In addition, the PDO between July to October is negatively significantly correlated with RX1day and RX5day ( $r=-0.289$ and $-0.282, p<0.05$, respectively). This indicates a close linkage between ENSO, $\mathrm{PDO}$ and precipitation extremes over the BTSSR.

The correlation analysis shows that PRCPTOT was significantly affected by summer SOI $(r=0.251$, $p<0.1)$, with a statistically significant effect on R95p $(r=0.271, p<0.05)$. RX1day and RX5day indices are positively correlated with summer SOI, but not at statistically significant levels $(r=0.201$ and 0.208 , $p>0.1$, respectively). In addition, R10 and R20 were also significantly positively correlated with the summer SOI ( $\mathrm{r}=0.314$ and $0.326, p<0.05$, respectively); CDD was significantly positively correlated with SOI from the previous November to March $(r=0.283, p<0.05)$, particularly with SOI from the previous December to February $(r=0.37, p<0.01)$.

\section{Discussion}

\subsection{Extreme Precipitation Trends}

In this study, all indices representing extreme precipitation showed negative trends over time based on data from most stations. In particular, the intensity indices (RX1day and RX5day) significantly decreased over time, at a 95\% confidence level. Similarly, decreasing trends in extreme precipitation 
have been observed in many other parts of the world, including southwestern Pakistan [22], the Hawaiian Islands [57], and northwestern Iran [58]. In China, many other studies have also found decreasing trends in extreme precipitation, in regions such as southeastern Tibet [59], northern Sichuan [60], and the Yellow River Basin [61]. In our study area, other precipitation extreme indices, such as R1, R10, R20, R95p, and PRCPTOT, showed a weak decreasing trend across most of this area (Table 2). These results highlight a tendency toward a drier climate in the BTSSR. PPL95 displayed a decreasing trend in our study area, and this is different from trends in Southeast Asia and in the western and central South Pacific [62], which found that the proportion of annual rainfall from extreme events increased at a majority of stations. Extreme precipitation indices such as RX1day, RX5day, R10, R20, R95p, and PRCPTOT, also followed an increasing global trend [2] in regions such as central and southern Asia [9], northwestern and southwestern China [12,14], and Xinjiang [63]. These previously reported results are in opposition to our study.

\subsection{Possible Mechanism of Extreme Precipitation Changes}

East Asian summer monsoon rainfall is associated with sea surface temperature (SST) conditions in the warm pool region and the nature of the association depends greatly on the precise location in the region. The western Pacific SST variations in warm pool region are associated with summer rainfall anomalies over China [64].

The BTSSR is located in the marginal region of EASM effects, resulting mainly in summer precipitation. Annual total precipitation has shown the great inter-decadal variability over the BTSSR. According to the above analysis, we speculated that when the sea surface temperature in the western Pacific warm pool is high (El Niño), the convection will be enhanced, with a stronger EASM; consequently, more abundant water vapor will be transported into northern China, and more frequent and stronger summer precipitation in the BTSSR. Conversely, the low sea surface temperature in western Pacific warm pool will lead to a weaker EASM, as well as less frequent and weaker summer precipitation in our study area. Over recent decades, the EASMI and SOI have presented decreasing trends, and the decline of the Asian monsoon circulation strength, and the PDO increasing trends contributed commonly to severe precipitation anomalies over this period. These would explain why the annual precipitation and frequency of heavy precipitation days decreased, but precipitation strength increased slightly over BTSSR.

Additionally, the Arctic sea ice loss causes large-scale anomaly circulation in mid-to-high latitude Eurasia with strong cooling over the Eurasian continent east of $50^{\circ} \mathrm{E}$ [65-68], which may impact the summer precipitation in the north of China [69]. The westerlies also have an important effect on the moisture budget, and the interannual variation of moisture convergence is the dominant factor in inducing variations in precipitation over higher latitudes in China [70]. Except for large-scale circulations, the topography may also affect the precipitation extremes. The impacts of monsoons, topography and their interaction mechanisms are very complicated.

\subsection{Potential Impacts on Environmental Change}

Precipitation is a main factor controlling vegetative growth and degraded-vegetation restoration in arid and semi-arid regions. In the BTSSR, indices associated with extreme precipitation, including R10, R20, RX1day, RX5day, R95p, PRCPTOT, and PPL95, showed an increasing trend between 1980 and 1998 (Figure 3). This provided more abundant water resources to support vegetative growth. In the same period, vegetation also increased over time, mainly caused by precipitation [71].

While it appears that vegetation in the BTSSR improved before 1998, there has been extensive land degradation in many areas of this region due to human activities, such as overgrazing, over-reclamation, deforestation, and coal mining. These conditions led to strong dust storms between 2000 and 2003. BTSSR is a significant source of dust storms during spring. As a sand source control project has been implemented between 2000 and 2014, the precipitation amounts (PRCPTOT) have increased, at a rate of approximately $49.7 \mathrm{~mm} /$ decade (Figure 3). This has provided more water to support 
vegetative growth, further enhancing the vegetation activity and restoration being done by the project itself [72-75]. Moreover, earlier growth during spring caused by climate warming could lead to vegetation covering the land earlier, reducing the occurrence of dust storms [76]. In addition, significant decreases in wind speed [42] and increasing spring precipitation [71] contribute to the reductions in storms. However, due to the longer-term decreases in precipitation amounts and extremes, mainly during summer and consumed by vegetative growth, thus reducing soil moisture during the following spring, if vegetation and wind conditions remain the same, dust storms would increase.

In this study area, both the maximum 1-day precipitation (RX1day) and the maximum 5-day precipitation (RX5day) significantly decreased over time. The extreme heavy precipitation indices, such as R10, R20, and R95p, also decreased albeit not at significant levels. The contribution of heavy rain to the annual precipitation total (PPL95) also declined. Shan et al. (2015) also showed a decreasing trend in potential evapotranspiration, at a decline of $-3.8 \mathrm{~mm} /$ decade [29]. These data suggest the hydrological cycle was weakened in the BTSSR. This may lead to less water runoff into inland lakes, especially flood runoff $[72,77]$, further reducing lake surface areas and water levels. Some studies [78,79] had shown the rapid loss of lakes on the Mongolian Plateau over the past few decades, especially in Inner Mongolia where precipitation has been a dominant driver in the lake changes. Our results align with these findings, as follows. First, Dali Nur Lake, located in the southeastern region, has experienced a shrinkage. Second, the water level in the Dai Hai Lake decreased at a rate of $-0.16 \mathrm{~mm}$ per year [80]. Third, the Huangqihai Lake in the northern part of the BTSSR has been in a dry period since the 1980s [81]. Due to the shrinkages of these lakes, wetlands around the lakes have declined, affecting aquatic plant growth and distribution. As wetlands disappear, amphibians and frogs, which are sensitive to humidity changes, are threatened; loss of these species further reduces wetland biodiversity. In the future, research should examine the effect of extreme precipitation on lakes and wetlands in the ecological restoration project.

From a long-term perspective, the extreme precipitation indices, including PRCPTOT, R95p, RX1day, RX5day, R10, and R20 etc., reveal significant spatial differences. Regions with increasing trends in precipitation extremes, primarily the midwestern part of the study area, could see increased soil moisture, further accelerating vegetation activity and restoration. This would reduce the occurrence of dust storms. In the Hetao Plain, a large agricultural irrigation area associated with the Yellow River, increasing precipitation may reduce the need for agricultural irrigation. The Haihe and West Liao River Basin are areas with water erosion, landslides, and debris flows [82,83]. Precipitation amounts and extremes decreased over time at most stations in these areas. This suggests a weakening for the possibility of mountain disasters, and a decrease in soil erosion. However, due to the decrease in precipitation amounts and extremes, the decreasing runoff may reduce the availability of water resources for metropolitan areas, such as Beijing and Tianjin. This could further exacerbate water shortages in these cities. In the Xilinguole grassland and Mu Us sandland, decreasing precipitation may accelerate the soil deficit, further impeding vegetative growth and restoration.

\section{Conclusions}

On the basis of daily precipitation data from 53 meteorological stations in the Beijing-Tianjin Sand Source Region (BTSSR) during 1960-2014, the temporal and spatial trends of extreme precipitation were analyzed by the Mann-Kendall test, Sen's slope estimator and linear regression. Furthermore, the possible causes and implications of changes in extreme precipitation were also studied. Similar spatial patterns were shown for all the indices, except for the consecutive dry days. At the whole-area scale, most precipitation extreme indices demonstrated decreasing trends with a statistically insignificant level; beyond that, the intensity indices exhibited significantly decreasing trends in RX1day and RX5day with a value of 1.41 and $2.05 \mathrm{~mm} /$ decade, respectively. Spatially, most stations experienced a decreasing trend in all indices for extreme precipitation over the past 55 years, except for SDII and R10, which indicated a general tendency toward a drier climate. Correlation analysis showed that the extreme precipitation in BTSSR is mainly affected by the El Niño-Southern Oscillation (ENSO), 
East Asian Summer Monsoon (EASM) and Pacific Decadal Oscillation (PDO). The decrease of ENSO and EASM, and the increase of PDO caused the decrease of extreme precipitations in BTSSR. Better understanding of the precipitation extremes for BTSSR may be useful in terms of regional planning for ecological restoration, natural hazards prevention and water management in the future. More attention should be paid to the variations of extreme precipitation due to these large-scale circulations for a clearer picture of the impact on environmental change in BTSSR.

Acknowledgments: This research was supported by Fundamental Research Funds of CAF (CAFYBB2017ZA006), the International Science and Technology Cooperation Program of China (2015DFR31130), National Key Research and Development Program of China (2016YFC0500908; 2016YFC0500801; 2016YFC0500804), and the National Natural Science Foundation of China (31670715; 41471029; 41271033; 41371500).

Author Contributions: Wei Wei, Zhongjie Shi, and Xiaohui Yang conceived the study; Zheng Wei, Yanshu Liu, Zhiyong Zhang, Genbatu Ge, Xiao Zhang contributed to analysis and manuscript preparation; Wei Wei and Zhongjie Shi processed and wrote the paper; Kebin Zhang, Baitian Wang and Hao Guo helped perform the analysis with constructive discussions; Zhongjie Shi and Xiaohui Yang contributed to the revision of the paper.

Conflicts of Interest: The authors declare no conflict of interest.

\section{References}

1. IPCC Climate Change. The Physical Science Basis. In Contribution of Working Group I to the Fifth Assessment Report of the Intergovernmental Panel on Climate Change; Cambridge University Press: Cambridge, UK, 2013.

2. Alexander, L.V.; Zhang, X.; Peterson, T.C.; Caesar, J.; Gleason, B.; Klein Tank, A.M.G.; Haylock, M.; Collins, D.; Trewin, B.; Rahimzadeh, F.; et al. Global observed changes in daily climate extremes of temperature and precipitation. J. Geophys. Res. 2006, 111, D05109.

3. IPCC Climate Change. The Physical Science Basis. In Contribution of Working Group I to the Fourth Assessment Report of the Intergovernmental Panel on Climate Change; Cambridge University Press: Cambridge, UK, 2007.

4. Parmesan, C.; Root, T.L.; Willig, M.R. Impacts of extreme weather and climate on terrestrial biota. Bull. Am. Meteorol. Soc. 2000, 81, 443-450. [CrossRef]

5. Peterson, T.C.; Manton, M.J. Monitoring changes in climate extremes: A tale of international collaboration. Bull. Am. Meteorol. Soc. 2008, 89, 1266-1271. [CrossRef]

6. Tierney, J.E.; Smerdon, J.E.; Anchukaitis, K.J.; Seager, R. Multidecadal variability in East African hydroclimate controlled by the Indian Ocean. Nature 2013, 493, 389-392. [CrossRef] [PubMed]

7. Lupikasza, E. Spatial and temporal variability of extreme precipitation in Poland in the period 1951-2006. Int. J. Climatol. 2010, 30, 991-1007. [CrossRef]

8. Donat, M.G.; Peterson, T.C.; Brunet, M.; King, A.D.; Almazroui, M.; Kolli, R.K.; Boucherf, D.; Al-Mulla, A.Y.; Nour, A.Y.; Aly, A.A.; et al. Changes in extreme temperature and precipitation in the Arab region: Long-term trends and variability related to ENSO and NAO. Int. J. Climatol. 2014, 34, 581-592. [CrossRef]

9. Klein Tank, A.M.G.; Peterson, T.C.; Quadir, D.A.; Dorji, S.; Zou, X.; Tang, H.; Santhosh, K.; Joshi, U.R.; Jaswal, A.K.; Kolli, R.K.; et al. Changes in daily temperature and precipitation extremes in central and south Asia. J. Geophys. Res. 2006, 111, D16105. [CrossRef]

10. You, Q.L.; Kang, S.C.; Aguilar, E.; Yan, Y.P. Changes in daily climate extremes in the eastern and central Tibetan Plateau during 1961-2005. J. Geophys. Res. 2008, 113, D7. [CrossRef]

11. Guo, P.W.; Zhang, X.K.; Zhang, S.Y.; Wang, C.L.; Zhang, X. Decadal variability of extreme precipitation days over Northwest China from 1963 to 2012. J. Meteorol. Res. 2014, 28, 1099-1113. [CrossRef]

12. Wang, H.J.; Chen, Y.N.; Chen, Z.S. Spatial distribution and temporal trends of mean precipitation and extremes in the arid region, northwest of China, during 1960-2010. Hydrol. Process. 2013, 27, 1807-1818. [CrossRef]

13. Fu, G.B.; Yu, J.J.; Yu, X.B.; Ouyang, R.L.; Zhang, Y.C.; Wang, P.; Liu, W.B.; Min, L.L. Temporal variation of extreme rainfall events in China, 1961-2009. J. Hydrol. 2013, 487, 48-59. [CrossRef]

14. Xu, X.; Du, Y.G.; Tang, J.P.; Wang, Y. Variations of temperature and precipitation extremes in recent two decades over China. Atmos. Res. 2011, 101, 143-154. [CrossRef]

15. Zhang, H.; Zhai, P.M. Temporal and spatial characteristics of extreme hourly precipitation over eastern China in the warm season. Adv. Atmos. Sci. 2011, 28, 1177-1183. [CrossRef] 
16. Zhang, K.X.; Pan, S.M.; Cao, L.G.; Wang, Y.; Zhao, Y.F.; Zhang, W. Spatial distribution and temporal trends in precipitation extremes over the Hengduan Mountains region, China, from 1961 to 2012. Quat. Int. 2014, 349, 346-356. [CrossRef]

17. Li, Y.G.; He, D.M.; Hu, J.M.; Cao, J. Variability of extreme precipitation over Yunnan Province, China 1960-2012. Int. J. Climatol. 2015, 35, 245-258. [CrossRef]

18. Lupikasza, E.B.; Hansel, S.; Matschullat, J. Regional and seasonal variability of extreme precipitation trends in southern Poland and central-eastern Germany 1951-2006. Int. J. Climatol. 2011, 31, 2249-2271. [CrossRef]

19. Jung, I.W.; Bae, D.H.; Kim, G. Recent trends of mean and extreme precipitation in Korea. Int. J. Climatol. 2011, 31, 359-370. [CrossRef]

20. Vincent, L.A.; Aguilar, E.; Saindou, M.; Hassane, A.F.; Jumaux, G.; Roy, D.; Booneeady, P.; Virasami, R.; Randriamarolaza, L.Y.A.; Faniriantsoa, F.R. Observed trends in indices of daily and extreme temperature and precipitation for the countries of the western Indian Ocean, 1961-2008. J. Geophys. Res. 2011, 116, D10108. [CrossRef]

21. Maeda, E.E.; Utsumi, N.; Oki, T. Decreasing precipitation extremes at higher temperatures in tropical regions. Nat. Hazards 2012, 64, 935-941. [CrossRef]

22. Hussain, M.S.; Lee, S. The regional and the seasonal variability of extreme precipitation trends in Pakistan. Asia-Pac. J. Atmos. Sci. 2013, 49, 421-441. [CrossRef]

23. AlSarmi, S.H.; Washington, R. Changes in climate extremes in the Arabian Peninsula: Analysis of daily data. Int. J. Climatol. 2014, 34, 1329-1345. [CrossRef]

24. Zhang, X.Y.; Cong, Z.T. Trends of precipitation intensity and frequency in hydrological regions of China from 1956 to 2005. Glob. Planet. Chang. 2014, 117, 40-51. [CrossRef]

25. Shao, Y.H.; Wu, J.M.; Ye, J.Y.; Liu, Y.H. Frequency analysis and its spatiotemporal characteristics of precipitation extreme events in China during 1951-2010. Theor. Appl. Climatol. 2015, 121, 775-787. [CrossRef]

26. Wu, J.J.; Zhao, L.; Zheng, Y.T.; Lu, A.F. Regional differences in the relationship between climatic factors, vegetation, land surface conditions, and dust weather in China's Beijing-Tianjin Sand Source Region. Nat. Hazards 2012, 62, 31-44. [CrossRef]

27. Yin, R.S.; Yin, G.P. China's primary programs of terrestrial ecosystem restoration: Initiation, implementation, and challenges. Environ. Manag. 2010, 45, 429-441. [CrossRef] [PubMed]

28. Wu, Z.T.; Wu, J.J.; Liu, J.H.; He, B.; Lei, T.J.; Wang, Q.F. Increasing terrestrial vegetation activity of ecological restoration program in the Beijing-Tianjin Sand Source Region of China. Ecol. Eng. 2013, 52, 37-50. [CrossRef]

29. Shan, N.; Shi, Z.J.; Yang, X.H.; Gao, J.X.; Cai, D.W. Spatiotemporal trends of reference evapotranspiration and its driving factors in the Beijing-Tianjin Sand Source Control Project Region, China. Agric. For. Meteorol. 2015, 200, 322-333. [CrossRef]

30. Frich, P.; Alexander, L.V.; Della-Marta, P.; Gleason, B.; Haylock, M.; Klein Tank, A.; Peterson, T. Observed coherent changes in climatic extremes during second half of the twentieth century. Clim. Res. 2002, 19, 193-212. [CrossRef]

31. Booth Evan, L.J.; Byearne, J.M.; Johnson, D.L. Climatic changes in western North America, 1950-2005. Int. J. Climatol. 2012, 32, 2283-2300. [CrossRef]

32. Wang, S.J.; Zhang, M.J.; Wang, B.L.; Sun, M.P.; Li, X.F. Recent changes in daily extremes of temperature and precipitation over the western Tibetan Plateau, 1973-2011. Quat. Int. 2013, 313, 110-117. [CrossRef]

33. Wang, X.L. Accounting for autocorrelation in detecting mean shifts in climate data series using the penalized maximal $t$ or F test. J. Appl. Meteorol. Clim. 2008, 47, 2423-2444. [CrossRef]

34. Kioutsioukis, I.; Melas, D.; Zerefos, C. Statistical assessment of changes in climate extremes over Greece (1955-2002). Int. J. Climatol. 2010, 30, 1723-1737. [CrossRef]

35. Im, E.S.; Jung, I.W.; Bae, D.H. The temporal and spatial structures of recent and future trends in extreme indices over Korea from a regional climate projection. Int. J. Climatol. 2011, 31, 72-86. [CrossRef]

36. Keggenhoff, I.; Elizbarashvili, M.; Amiri-Farahani, A.; King, L. Trends in daily temperature and precipitation extremes over Georgia, 1971-2010. Weather Clim. Extremes 2014, 4, 75-85. [CrossRef]

37. Goovaerts, P. Ordinary cokriging revisited. Math. Geol. 1998, 30, 21-42. [CrossRef]

38. Paparrizos, S.; Maris, F.; Matzarakis, A. Mapping of drought for Sperchios River basin in central Greece. Hydrol. Sci. J. 2016, 61, 881-891. [CrossRef]

39. Nistor, M.M. Spatial distribution of climate indices in the Emilia-Romagna region. Meteorol. Appl. 2016, 23, 304-313. [CrossRef] 
40. Mann, H.B. Nonparametric tests against trend. Econometrica 1945, 13, 245-259. [CrossRef]

41. Kendall, M.G. Rank Correlation Methods, 4th ed.; Charles Griffin: London, UK, 1975.

42. Shi, Z.J.; Shan, N.; Xu, L.H.; Yang, X.H.; Gao, J.X.; Guo, H.; Zhang, X.; Song, A.Y.; Dong, L.S. Spatiotemporal variation of temperature, precipitation and wind trends in a desertification prone region of China from 1960 to 2013. Int. J. Climatol. 2016. [CrossRef]

43. Shi, Z.J.; Xu, L.H.; Yang, X.H.; Guo, H.; Dong, L.S.; Song, A.Y.; Zhang, X.; Shan, N. Trends in reference evapotranspiration and its attribution over the past 50 years in the Loess Plateau, China: Implications for ecological projects and agricultural production. Stoch. Environ. Res. Risk Assess. 2017, 31, 257-273. [CrossRef]

44. Xu, L.H.; Shi, Z.J.; Wang, Y.H.; Zhang, S.L.; Chu, X.Z.; Yu, P.T.; Xiong, W.; Zuo, H.J.; Wang, Y.N. Spatiotemporal variation and driving forces of reference evapotranspiration in Jing River Basin, northwest China. Hydrol. Process. 2015, 29, 4846-4862. [CrossRef]

45. Xu, L.H.; Shi, Z.J.; Wang, Y.H.; Chu, X.Z.; Yu, P.T.; Xiong, W.; Zuo, H.J.; Zhang, S.L. Agricultural irrigation-induced climatic effects: A case study in the middle and southern Loess Plateau area, China. Int. J. Climatol. 2016. [CrossRef]

46. Sen, P.K. Estimates of the regression coefficient based on Kendall's tau. J. Am. Stat. Assoc. 1968, 63, 1379-1389. [CrossRef]

47. Yue, S.; Pilon, P.; Phinney, B.; Cavadias, G. The influence of autocorrelation on the ability to detect trend in hydrological series. Hydrol. Process. 2002, 33, 2328-2340. [CrossRef]

48. Dinpashoh, Y.; Jhajharia, D.; Fakheri-Fard, A.; Singh, V.P.; Kahya, E. Trends in reference crop evapotranspiration over Iran. J. Hydrol. 2011, 399, 422-433. [CrossRef]

49. Jhajharia, D.; Dinpashoh, Y.; Kahya, E.; Singh, V.P.; Fakheri-Fard, A. Trends in reference evapotranspiration in the humid region of northeast India. Hydrol. Process. 2012, 26, 421-435. [CrossRef]

50. Trenberth, K.E.; Jones, P.D.; Ambenje, P.; Bojariu, R.; Easterling, D.; Klein Tank, A.; Parker, D.; Rahimzadeh, F.; Renwick, J.A.; Rusticucci, M.; et al. Observations: Surface and Atmospheric Climate Change. In Climate Change 2007: The Physical Science Basis; Cambridge University Press: Cambridge, UK, 2007.

51. Lu, R. Interannual variation of North China rainfall in rainy season and SSTs in the equatorial eastern Pacific. Chin. Sci. Bull. 2005, 50, 2069-2073. [CrossRef]

52. Wu, R.G.; Wang, B. A contrast of the East Asian summer Monsoon-ENSO relationship between 1962-77 and 1978-93. J. Clim. 2002, 15, 3266-3279. [CrossRef]

53. Li, J.P.; Zeng, Q.C. A new monsoon index and the geographical distribution of the global monsoons. Adv. Atmos. Sci. 2003, 20, 299-302.

54. Li, J.P.; Zeng, Q.C. A unified monsoon index. Geophys. Res. 2002, 29, 1274. [CrossRef]

55. Mantua, N.J.; Hare, S.R.; Zhang, Y.; Wallace, J.M.; Francis, R.C. A Pacific interdecadal climate oscillation with impacts on salmon production. Bull. Am. Meteorol. Soc. 1997, 78, 1069-1079. [CrossRef]

56. Suppiah, R. Trends in the southern oscillation phenomenon and Australian rainfall and changes in their relationship. Int. J. Climatol. 2004, 24, 269-290. [CrossRef]

57. Chen, Y.R.; Chu, P.S. Trends in precipitation extremes and return levels in the Hawaiian Islands under a changing climate. Int. J. Climatol. 2014, 34, 3913-3925. [CrossRef]

58. Najafi, M.R.; Moazami, S. Trends in total precipitation and magnitude-frequency of extreme precipitation in Iran, 1969-2009. Int. J. Climatol. 2016, 36, 1863-1872. [CrossRef]

59. Zhang, J.S.; Shen, X.J.; Wang, B.L. Changes in precipitation extremes in Southeastern Tibet, China. Quat. Int. 2015, 380, 49-59. [CrossRef]

60. Zou, X.K.; Ren, F.M. Changes in regional heavy rainfall events in China during 1961-2012. Adv. Atmos. Sci. 2015, 32, 704-714. [CrossRef]

61. Wang, W.G.; Shao, Q.X.; Yang, T.; Peng, S.Z.; Yu, Z.B.; Taylor, J.; Xing, W.Q.; Zhao, C.P.; Sun, F.C. Changes in daily temperature and precipitation extremes in the Yellow River Basin, China. Stoch. Environ. Res. Risk Assess. 2013, 27, 401-421. [CrossRef]

62. Manton, M.J.; Della-Marta, P.M.; Haylock, M.R.; Hennessy, K.J.; Nicholls, N.; Chambers, L.E.; Collins, D.A.; Daw, G.; Finet, A.; Gunawan, D.; et al. Trends in extreme daily rainfall and temperature in southeast Asia and the south Pacific: 1961-1998. Int. J. Climatol. 2001, 21, 269-284. [CrossRef]

63. Zhang, Q.; Singh, V.P.; Li, J.F.; Jiang, F.Q.; Bai, Y.G. Spatio-temporal variations of precipitation extremes in Xinjiang, China. J. Hydrol. 2012, 434, 7-18. [CrossRef] 
64. Simmonds, I.; Bi, D.H.; Yan, B.L. Relationships between summer rainfall over China and ocean temperatures in the tropical western Pacific. J. Meteorol. Soc. Jpn. 1996, 74, 273-279. [CrossRef]

65. Luo, D.H.; Xiao, Y.Q.; Yao, Y.; Dai, A.G.; Simmonds, I.; Franzke, C.L.E. Impact of Ural blocking on winter warm Arctic-Cold Eurasian anomalies. Part I: Blocking-induced amplification. J. Clim. 2016, 29, 3925-3947. [CrossRef]

66. Luo, D.H.; Xiao, Y.Q.; Diao, Y.N.; Dai, A.G.; Franzke, C.L.E.; Simmonds, I. Impact of Ural blocking on winter warm Arctic-Cold Eurasian anomalies. Part II: The link to the North Atlantic Oscillation. J. Clim. 2016, 29, 3949-3971. [CrossRef]

67. Luo, D.H.; Yao, Y.; Dai, A.G.; Simmonds, I.; Zhong, L.H. Increased quasi-stationarity and persistence of winter ural blocking and eurasian extreme cold events in response to arctic warming. Part II: A theoretical explanation. J. Clim. 2017. [CrossRef]

68. Yao, Y.; Luo, D.H.; Dai, A.G.; Simmonds, I. Increased Quasi-stationarity and persistence of winter Ural blocking and Eurasian extreme cold events in response to Arctic warming. Part I: Insights from observational analyses. J. Clim. 2017. [CrossRef]

69. Zhang, J.N. Possible Effects of Arctic Sea Ice Anomalies on Summer Climate in China; Chinese Academy of Meteorological Sciences Press: Beijing, China, 2011.

70. Simmonds, I.; Bi, D.H.; Hope, P. Atmospheric water vapor flux and its association with rainfall over China in summer. J. Clim. 1999, 12, 1353-1367. [CrossRef]

71. Shan, N. Vegetation Index (NDVI) Responses to Climate Change in Beijing-Tianjin Sand Source Region; China Forest Science Research Institute: Beijing, China, 2013.

72. Wu, Z.; Wu, J.; He, B.; Liu, J.; Wang, Q.; Zhang, H.; Liu, Y. Drought offset ecological program-induced increase in vegetation activity in the Beijing-Tianjin Sand Source Region, China. Environ. Sci. Technol. 2014, 48, 12108-12117. [CrossRef] [PubMed]

73. Yan, E.P.; Lin, H.; Dang, Y.F.; Xia, Z.Z. The spatiotemporal changes of vegetation cover in Beijing-Tianjin sandstorm source control region during 2000-2012. Acta Ecol. Sin. 2014, 34, 5007-5020.

74. Yang, Y.L.; Sun, Y.L.; Wang, Z.L.; Kang, J. Persistence in vegetation cover changes in Beijing-Tianjin Sandstorm Source Control Region. Acta Ecol. Sin. 2016, 36, 47-53.

75. Li, X.S.; Wang, H.Y.; Zhou, S.F.; Sun, B.; Gao, Z.H. Did ecological engineering projects have a significant effect on large-scale vegetation restoration in Beijing-Tianjin Sand Source Region, China? A remote sensing approach. Chin. Geogr. Sci. 2016, 26, 216-228. [CrossRef]

76. Fan, B.H.; Guo, L.; Li, N.; Chen, J.; Lin, H.; Zhang, X.Y.; Shen, M.G.; Rao, Y.H.; Wang, C.; Ma, L. Earlier vegetation green-up has reduced spring dust storms. Sci. Rep. 2014, 4, 6749. [CrossRef] [PubMed]

77. Zhang, H.Z.; Tian, M.Z.; Guo, J.; Yang, J. The dynamic monitoring of Dalinur Lake in Inner Mongolia during 1999-2010 based on RS and GIS. J. Arid Land Resour. Environ. 2012, 26, 41-46.

78. Tao, S.L.; Fang, J.Y.; Zhao, X.; Zhao, S.Q.; Shen, H.H.; Hu, H.F.; Tang, Z.Y.; Wang, Z.H.; Guo, Q.H. Rapid loss of lakes on the Mongolian Plateau. PNAS 2014, 112, 2281-2286. [CrossRef] [PubMed]

79. Liu, H.; Yin, Y.; Piao, S.; Zhao, F.; Engels, M.; Ciais, P. Disappearing Lakes in Semiarid Northern China: Drivers and Environmental Impact. Environ. Sci. Technol. 2013, 47, 12107-12114. [CrossRef] [PubMed]

80. Sun, Z.D.; Jiang, J.H.; Huang, Q. Analysis of climate and hydrological change in Daihai Basin in the late 50 years. Water. Resour. Prot. 2005, 21, 1-8.

81. Yu, L.L.; Qin, Y.C.; Liu, J.S. Analysis of water resources characteristics of Huangqihai river basin. Inner Mongolia Water Resour. 2013, 2, 36-38.

82. Du, H.; Xia, J.; Zeng, S.D.; She, D.X.; Liu, J.J. Variations and statistical probability characteristic analysis of extreme precipitation events under climate change in Haihe River Basin, China. Hydrol. Process. 2012, 28, 913-925. [CrossRef]

83. Chen, Y.; Chen, X.Y.; Ren, G.Y. Variation of extreme precipitation over Large River Basins in China. Adv. Clim. Chang. Res. 2011, 2, 108-114. [CrossRef]

(C) 2017 by the authors. Licensee MDPI, Basel, Switzerland. This article is an open access article distributed under the terms and conditions of the Creative Commons Attribution (CC BY) license (http:/ / creativecommons.org/licenses/by/4.0/). 